\title{
Uji Potensi Beberapa Jenis Pupuk Hayati \\ Pada Budidaya Bawang Merah (Allium cepa L.)
}

\section{Testing the Potency of Various Biological Fertilizer on Shallots (Allium cepa L.) Farming}

\author{
Juniawan \\ Balai Besar Pelatihan Pertanian (BBPP) Ketindan, Jl. Ketindan No. 1 Lawang \\ e-mail: juniawanwi@gmail.com
}

\begin{abstract}
ABSTRAK
Penelitian ini bertujuan untuk mengetahui kemampuan dari beberapa jenis pupuk hayati yaitu jamur mikoriza species Glomus mosseae, Trichoderma spp., Azospirilium sp., Azotobacter sp., dan Pseudomonas sp. dalam peningkatan produksi bawang merah yang ditanam di lahan praktek BBPP Ketindan. Penelitian ini menggunakan Rancangan Acak Kelompok (RAK) dimulai dengan pengolahan tanah, pembuatan bedengan, pemberian pupuk kompos lalu ditutup mulsa plastik. Selanjutnya dibuat lubang tanam dan setiap lubang ditanami satu siung. Setelah berumur 10 hari dilakukan inokulasi jamur sebanyak 10 gram pada setiap anakan. Aplikasi diulang pada umur 30 HST. Tanaman dipelihara dengan penyiraman dan aplikasi ekstrak daun mimba dua kali sepekan. Setelah berumur 70 hari, tanaman dipanen, ditimbang lalu dikering-anginkan selama 30 hari, lalu ditimbang kembali. Data ditabulasi, dianalisis dan disimpulkan. Hasilnya menunjukkan hasil yang bervariasi, berturut-turut dari jumlah siung $(264,220,253)$, berat basah $(3.495,2.585$, $3.100)$ dan berat kering $(2.238,1,655,2.002)$. Data ini menunjukkan bahwa penggunaan pupuk hayati perlu dipertimbangkan sebagai salah satu input untuk meningkatkan produksi bawang merah.
\end{abstract}

Kata kunci: Mikoriza, Trichoderma, bawang merah, berat kering

\section{ABSTRACT}

This study aims to determine the ability of several types of biological fertilizers of mycorrhizal fungi Glomus mosseae, Trichoderma spp., Azospirilium sp., Azotobacter sp., and Pseudomonas sp. in increasing the production of red shallots on National Agricultural Training Center (NATC) Ketindan. This study uses a Randomized Block Design (RBD) started with soil processing, making beds, giving compost fertilizer and then closing with plastic mulch. Each hole is planted with one bulb of red shallot. After 10 days after planting, each plant is inoculated with 10 grams of mycorrhizal fungi Glomus mosseae, Trichoderma spp., Azospirilium sp., Azotobacter sp., and Pseudomonas sp. The application is repeated at 30 HST. Plants are maintained by watering and application of neem leaf extract twice a week. After 70 days, plants are harvested, weighed, dried for 30 days and then weighed again. The resulting data is tabulated, analyzed and concluded. The results showed varied results, from the number of bulbs (264, 220, 253), wet weight $(3,495,2,585,3,100)$ and dry weight $(2,238,1,655,2,002)$ respectively. This data shows that the use of biological fertilizers can be considered as one of the inputs to increase red shallot production.

Keyword: Mycorrhizae, Trichoderma, Red Shallot, Dry Weight 


\section{PENDAHULUAN}

Bawang merah (Allium cepa.L.) merupakan komoditas hortikultura unggulan yang mempunyai nilai ekonomis tinggi, disukai petani, berumur genjah, cocok ditanaman pada aneka jenis lahan dan memiliki potensi untuk terus dikembangkan. Terdapat beberapa alasan pentingnya pengembangan bawang merah di Indonesia, antara lain: (1) tergolong sebagai komoditas bernilai ekonomis tinggi walaupun memiliki jumlah produksi dan harga yang sangat fluktuatif; (2) merupakan salah satu komoditas sayuran unggulan nasional sesuai dengan program sukses Kementerian Pertanian Tahun 2016;

(3) sebagai bahan makanan yang penting dalam hampir seluruh menu masakan di Indonesia karena memiliki kandungan berbagai macam senyawa yang berguna bagi kesehatan manusia; (4) memiliki prospek ekspor yang baik dan menjadi komoditas substitusi impor; (5) mempunyai daya adaptasi yang luas baik di lahan kering dan lahan irigasi teknis, dan (6) menyerap banyak tenaga kerja, (7) spektrum pasarnya luas mulai dari pasar tradisional, pasar modern hingga industri pengolahan.

Komoditas bawang merah telah banyak dibudidayakan oleh petani baik secara tradisional maupun intensif baik pada agroekosistem lahan sawah dataran rendah beririgasi maupun lahan kering dataran tinggi non-irigasi. Bawang merah sangat cocok ditanam pada awal musim kemarau, walaupun tidak menutup kemungkinan ditanam pada musim hujan.

Harga biasanya akan melonjak drastis pada saat awal musim hujan karena permintaan pasar yang sangat besar dan berkaitan dengan datangnya beberapa hari besar keagamaan. Permintaan pasar yang terjadi biasanya tidak diimbangi dengan pasokan yang mencukupi karena banyak petani yang enggan membudidayakannya. Tentunya hal itu dapat dimaklumi karena membudidayakan bawang merah di musim hujan sangat berisiko, yakni kegagalan panen akibat cuaca yang tidak mendukung dan serangan hama penyakit yang bertubitubi, sehingga produksinya menjadi tidak maksimal, padahal bawang merah produksi idealnya dapat mencapai 20 ton/hektar.

Teknologi budidaya bawang merah di luar musim (off season) sangat diperlukan dalam rangka meningkatkan produksi dan pendapatan petani sehingga dapat menyangga kebutuhan masyarakat yang terus bertambah dan menunjang kestabilan harga melalui ketersediaan pasokan di sepanjang musim. Salah satu teknologi budidaya bawang merah yang dapat diterapkan pada musim hujan adalah menggunakan varietas unggul yang mampu beradaptasi di musim hujan seperti Sembrani dan Bauji serta penggunaan mulsa baik mulsa jerami maupun plastik hitam perak (MPHP). Mulsa berguna untuk mengatur kelembaban dan memantulkan sinar matahari ke daun bawang merah agar tetap bersih dari embun dan air hujan. Melalui teknologi tersebut diharapkan dapat memberikan masukan kepada petani tentang teknologi budidaya yang baik dan analisis usahatani bawang merah di luar musim serta nilai tambah yang diperoleh dengan kegiatan pascapanen dan pengolahan hasil, sehingga dapat meningkatkan pendapatan dan kesejahteraan petani.

Pupuk hayati adalah mikroorganisme yang melalui aktifitas biologisnya dapat membantu tanaman dalam memperoleh asupan unsur hara makro dan atau unsur hara mikro yang dibutuhkan tanaman. Jamur mikoriza, khususnya Glomus mosseae. dapat menyediakan unsur P bagi tanaman. Jamur Trichoderma spp. dapat menghasilkan enzim yang dapat berfungsi sebagai katalisator dalam mempercepat proses metabolisme pada tanaman sehingga terjadi pertumbuhan yang lebih cepat, sedangkan bakteri Azospirilium sp., Aspergillus niger, Penicillium sp., Pantoea sp., Streptomyces sp. dapat memfiksasi Nitrogen dari udara sehingga tersedia untuk tanaman. Tujuan yang ingin diperoleh dari kegiatan penelitian ini adalah untuk mengetahui pengaruh dari setiap jenis mikroorganisme pupuk hayati 
yang diuji terhadap dayahasil dari tanaman bawang merah.

\section{METODE PENELITIAN}

Metode penelitian yang digunakan adalah Rancangan Acak Kelompok (RAK) dengan 3 (tiga) ulangan dan 1 (satu) kontrol yaitu:

1. K1 : kompos + Trichoderma sp.

2. $\mathrm{K} 2$ : kompos + mikoriza Glomus mosseae.

3. K3 : kompos + Petrobio (Azospirilium sp., Aspergillus niger, Penicillium sp., Pantoea sp., Streptomyces sp.)

4. Kontrol

Variabel yang diteliti adalah jumlah siung, berat basah dan berat kering. Berat basah dihitung langsung ketika panen. Selanjutnya siung bawang merah beserta daunnya lalu dikering-anginkan selama 30 (tiga puluh) hari setelah panen lalu ditimbang. Data yang diperoleh ditabulasi dan diolah dengan program Excel untuk selanjutnya dianalisis.

\section{Bahan}

Beberapa jenis bahan yang diperlukan untuk penelitian ini adalah bibit bawang merah varietas Bauji, kompos, mikoriza Glomus mosseae, Trichoderma spp., Petrobio (Azospirilium sp., Aspergillus niger, Penicillium sp., Pantoea sp., Streptomyces sp.), dan daun mimba. Sedangkan alat-alat yang dibutuhkan adalah cangkul, alat pelubang plastik, MPHP, timbangan, sprayer, ember plastik, gayung berskala, masker dan sarung tangan plastik.

\section{Pelaksanaan Penelitian}

\section{Tahap I : Pengolahan tanah}

Proses pengolahan tanah dilakukan dengan menggunakan traktor roda dua, Setelah tanahnya halus lalu diratakan untuk selanjutnya dibagi menjadi beberapa bedeng sesuai dengan kebutuhan. Setiap petak/bedeng perlakuan berukuran PxLxT (2 $\mathrm{m} \times 1 \mathrm{~m} \mathrm{x} 30 \mathrm{~cm}$ ) dengan jarak antar bedeng selebar $50 \mathrm{~cm}$. Sehingga untuk seluruh perlakuan dibutuhkan 12 bedeng. Bedengan yang sudah siap ditaburi pupuk kompos secara merata. MPHP yang sudah disiapkan dipasang lalu dilubangi dengan jarak $10 \mathrm{~cm}$ x $10 \mathrm{~cm}$. Lahan direndam selama 12 jam. Keesokan harinya bawang merah ditanam.

Setiap lubang ditanam satu siung dengan kedalaman sekitar $1,5 \mathrm{~cm}$ pada posisi tegak. Kebutuhan bibit sebanyak 60 siung untuk setiap perlakuan.

\section{Tahap II : Aplikasi pupuk hayati pertama}

Setelah bawang merah berumur 10 hari (HST) ditaburi dengan pupuk hayati sebanyak 10 gram untuk setiap tanaman. Jenis pupuk hayati yang diberikan sesuai dengan perlakuan. Setelah ditaburi lalu disiram dengan air bersih sampai tanahnya basah. Untuk pencegahan serangan hama penyakit yang menyerang tanaman di atas tanah maka disemprot dengan ekstrak daun mimba dengan dosis $125 \mathrm{ml} /$ tangki. Penyemprotan diulangi setiap 4 (empat) hari hingga menjelang panen.

\section{Tahap III : Aplikasi pupuk hayati kedua}

Pada saat bawang merah berumur 30 (tiga puluh) HST, aplikasi pupuk hayati diulang sekali lagi dengan dosis dan teknis yang sama dengan perlakuan pertama.

\section{HASIL DAN PEMBAHASAN}

\section{Hasil Penelitian}

Hasil penelitian terhadap pengaruh aplikasi pupuk hayati terhadap jumlah siung dan bobot basah (produksi) bawang merah menunjukkan bahwa perlakuan dengan pupuk hayati mikoriza Glomus mosseae diperoleh siung berkisar antara 7-19 buah. Secara akumulatif untuk mikoriza sebanyak 264, sedangkan Petrobio, Trichoderma dan kontrol masing-masing 253, 220 dan 203. Untuk bobot basah dan kering juga bervariasi pada setiap perlakuan. Bobot basah siung tertinggi diperoleh sebagai hasil perlakuan dengan mikoriza yaitu 3.495 gram, diikuti oleh Petrobio (3.000 gram), 
Trichoderma sp. (2.585 gram), dan kontrol (2.480 gram). Sedangkan bobot kering dari produksi bawang merah ternyata juga bervariasi, mulai dari hasil perlakuan dengan jamur mikoriza (2.238 gram), diikuti berturut-turut Petrobio (2.002 gram), Trichoderma (1.655 gram) dan kontrol (1.592 gram), seperti tertera pada Tabel 1. dan Gambar 1.

Tabel 1. Pengaruh Penggunaan Pupuk Hayati Terhadap Produksi Bawang Merah

\begin{tabular}{cccc}
\hline $\begin{array}{c}\text { Jenis Pupuk } \\
\text { Hayati }\end{array}$ & $\begin{array}{c}\text { Jumlah } \\
\text { Siung }\end{array}$ & $\begin{array}{c}\text { Berat } \\
\text { Basah } \\
\text { (gram }\end{array}$ & $\begin{array}{c}\text { Berat } \\
\text { Kering } \\
\text { (gram) }\end{array}$ \\
\hline Trichoderma & 220 & 2585 & 1655 \\
Petrobio & 253 & 3000 & 2002 \\
Mikoriza & 264 & 3495 & 2238 \\
Kontrol & 203 & 2480 & 1592 \\
\hline
\end{tabular}

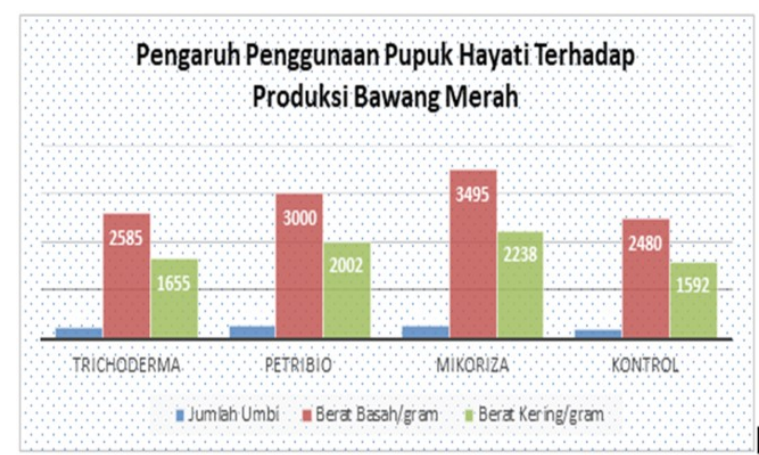

Gambar 1. Grafik Pengaruh Aplikasi Pupuk Hayati Terhadap Produksi Bawang Merah

\section{Pembahasan}

Perbedaan jumlah siung, bobot basah dan bobot kering dari bawang merah terjadi karena perbedaan perlakuan, jenis pupuk hayati dan jumlah ulangan perlakuan. Setiap perlakuan memberikan hasil yang berbeda. Ini berarti bahwa respon dari bawang merah berbeda terhadap setiap perlakuan yang diberikan.

\section{Aplikasi jamur mikoriza Glomus musseae atau jamur VAM (Vesikulair arbuskuler mikoriza)}

rerata memberikan hasil yang tertinggi bila dibandingkan dengan perlakuan yang lain. Hal ini terjadi karena jamur mikoriza mempunyai beberapa fungsi yang berbeda dengan jamur yang lain, yaitu:

a. Sebagai jamur antagonis, artinya jamur VAM mampu berkompetisi dengan mikoorganisme patogen dalam hal ruang tumbuh dan makanan, sehingga patogen terdesak dan tidak mendapatkan ruang dan makanan. Secara perlahan patogen akan kerdil dan akhirnya mati. Matinya mikroba patogen akan berpengaruh positif terhadap tanaman karena dalam pertumbuhannya tidak mendapatkan gangguan dari patogen, sehingga akan tumbuh dan berkembang sebagaimana mestinya. Tanaman dapat menyerap air dan unsur hara secara maksimal, baik unsur hara makro maupun unsur hara mikro. Serapan yang optimal terhadap unsur hara mempengaruhi perkembangan akar, pembentukan siung, dan kokohnya daun akibat kompaknya struktur sel. Daun yang kokoh tegak dengan warna hijau merata, akan meningkatkan bagian yang terpapar sinar matahari dan intensitas fotosintesis, sehingga menambah materi bahan untuk proses metabolisme tanaman. Proses metabolisme akan menghasilkan metabolik primer dan sekunder.

b. Jamur VAM dapat meningkatkan ketersediaan unsur $\mathrm{P}$ (Phosfor) bagi tanaman karena mikoriza mampu memutuskan rantai unsur hara $\mathrm{P}+++$ menjadi $\mathrm{P}++$ yang kemudian tersedia untuk tanaman. Unsur Fosfor digunakan tanaman untuk pembentukan akar, memperkokoh duduk daun dan meningkatkan kerapatan sel. Sel yang rapat dapat meningkatkan translokasi air dan unsur hara, mencegah tusukan stylet dari hama pencucuk- penghisap, dan mempertahan bobot (tonase) siung. Cendawan mikoriza arbuskula dapat membantu tanaman dalam penyerapan unsur hara, terutama hara $\mathrm{P}$ pada kondisi unsur $\mathrm{P}$ tersedia rendah pada 
tanah (Bolan,1991), hara N, K, dan Mg (Sieverding, 1991), Cu, Zn, Mn, B, dan Mo (Smith dan Read, 1997), Ca, $\mathrm{Mg}, \mathrm{Fe}$, dan S (Widiastuti dan Tahardi, 1993), serta meningkatkan toleransi tanaman terhadap penyakit akar, kekeringan, dan suhu tanah yang tinggi (De La Cruz, 1981).

c. Membantu tanaman dalam menjangkau air dengan menghubungkan ujung bulu akar tanaman dengan permukaan air, sehingga kebutuhan tanaman terhadap air akan terpenuhi. Kandungan air yang cukup dapat mempertahankan turgor tanaman, menjaga kelancaran translokasi air dan unsur hara. Dengan begitu, tanaman menjadi tahan terhadap cekaman air dan para petani bawang merah dapat mengurangi intensitas penyiraman tanaman.

d. Menghasilkan enzim yang dalam pertumbuhan dan perkembangan tanaman akan berperan sebagai katalisator dalam proses metabolisme sehingga pertumbuhan tanaman akan terpacu lebih cepat. Tanaman akan tumbuh lebih cepat, bobot lebih berat dan ketahanannya terhadap serangan hama penyakit lebih tinggi.

\section{Penggunaan Petrobio}

Petrobio adalah pupuk hayati yang mengandung beberapa mikroorganisme yaitu Azospirilium sp., Aspergillus niger, Penicillium sp., Pantoea sp., Streptomyces sp. Kelima bakteri ini mempunyai peranan penting didalam meningkatkan pertumbuhan dan perkembangan tanaman.

Azospirillum spp. dibagi menjadi dua yaitu bakteri yang membentuk bintil akar dan bakteri yang tidak membentuk bintil akar. Contoh dari bakteri yang membentuk bintil akar yaitu Rhizobium dan Bradyrhizobium, sedangkan bakteri yang tidak membentuk bintil contohnya yaitu Azotobacter dan Azospirillum. Azospirillum merupakan salah satu bakteri penambat nitrogen yang hidup bebas dan dapat berasosiasi dengan rumput . Ada beberapa spesies Azospirillum yaitu Azospirillum brasilense, Azospirillum lipoferum, Azospirillum amazonense dan Azospirillum halopraeferens. Azospirillum termasuk bakteri penambat nitrogen nonsimbiotik yang hidup bebas di dalam tanah, baik di sekitar maupun dekat dengan perakaran. Nitrogen yang ditambat oleh Azospirillum akan diserap oleh tanaman dalam bentuk amonium dan nitrat. Azospirillum sp juga mampu menghasilkan zat pengatur tumbuh seperti IAA (Indol Acetic Acid), giberelin, auksin, serta senyawa yang menyerupai sitokinin. (Rao, 1994)

Azospirillum merupakan bakteri penambat nitrogen dan penghasil zat tumbuh yang hidup berasosiasi dengan perakaran tanaman pada daerah rizosfer, terutama pada rumput-rumputan dan serealia. Peran menguntungkan Azospirillum antara lain dapat menyebabkan perubahan morfologi akar seperti peningkatan jumlah rambut akar, perpanjangan akar, dan luas permukaan akar yang disebabkan oleh produksi asam indol asetat (IAA) yang dihasilkan oleh Azospirillum, meningkatkan kecepatan penyerapan air dan nutrisi dari tanah, mengikat $\mathrm{N}_{2}$ dari udara, meningkatkan penyerapan $\mathrm{N}, \mathrm{P}$ dan $\mathrm{K}$ serta akumulasi bahan kering pada tanaman jagung, sorgum, gandum, dan setaria, dapat memproduksi auksin, sitokinin, dan giberelin, serta dapat memproduksi allelopati, bakteriosin, atau antibiotik (Okon, 1984, Okon and Kapulnik, 1986).

Beberapa jenis mikroba yang hidup di daerah perakaran (rhizosfer) seperti Azospirillum sp., Azotobacter sp., dan Enterobacter sp., dapat menguntungkan bagi pertumbuhan tanaman. Mikroba tersebut untuk datang dan hidup di rhizosfer karena tanaman mengeluarkan eksudat akar yang dapat berperan sebagai sumber nutrisi bagi mikroba. Sedangkan mikroba mengeluarkan metabolit berupa senyawasenyawa aktif (salah satunya fitohormon) yang digunakan oleh tanaman untuk pertumbuhan dan perkembangannya. Ini menjadi bukti terjadi relasi yang saling menguntungkan (simbiosis mutualistis) antara mikroba dengan tanaman akibat 
adanya eksudat akar. Eksudat menyebabkan populasi mikroba di daerah rhizosfer jauh lebih tinggi daripada di tanah biasa (Akbari et al. 2007).

\section{Aplikasi jamur Trichoderma spp.}

Untuk melihat kemampuan jamur ini dalam meningkatkan keragaan tanaman bawang merah menuju peningkatan produksi. Jamur Trichoderma spp. merupakan salah satu jenis mikroorganisme fungsional yang dikenal luas sebagai pupuk biologis tanah, biofungisida, organisme pengurai, agen hayati dan stimulator pertumbuhan tanaman. Trichoderma spp. dapat menghambat pertumbuhan serta penyebaran racun jamur penyebab penyakit bagi tanaman.

Penggunaan pupuk biologis dan agen hayati Trichoderma spp. sangat efektif mencegah penyakit busuk pangkal batang, busuk akar yang menyebabkan tanaman layu, dan penyakit jamur akar putih. Penggunaan pupuk biologis Trichoderma spp.. memang tidak memperlihatkan dampak secara langsung seperti pupuk ataupun fungisida kimia tetapi jika digunakan secara berkala akan memberikan manfaat yang lebih baik daripada pupuk dan fungisida

kimia.

Trichoderma spp. merupakan cendawan yang termasuk dalam kelas ascomycetes, banyak ditemukan di dalam tanah hutan maupun tanah pertanian atau pada tunggul kayu, tumbuh dengan baik pada suhu $6^{\circ} \mathrm{C}-41^{\circ} \mathrm{C}$ dengan $\mathrm{pH}$ optimum 3 - 7 dan Sukrosa dan glukosa merupakan karbon utamanya. Jamur ini berbiak menggunakan konidia (spora). Bila disimpan pada ruangan bersih dan terhindar dari sinar matahari. Trichoderma spp. akan terlihat tumbuh pada media beras atau dedak halus setelah satu sampai dua minggu.

\section{KESIMPULAN}

Kegiatan penelitian ini mendapatkan data yang sangat positif untuk budidaya bawang merah menggunakan pupuk hayati yaitu aplikasi jamur mikoriza mampu menghasilkan jumlah siung berkisar 7-19 buah. Secara akumulasi berturut-turut mikoriza (264 buah), Petrobio (253), Trichoderma (220) dan kontrol (203). Bobot basah siung tertinggi diperoleh sebagai hasil perlakuan dengan mikoriza (3.495 gram), Petrobio (3.000 gram), Trichoderma sp. (2.585 gram), dan kontrol (2.480 gram). Sedangkan bobot kering beruturut-turut jamur mikoriza (2.238 gram), Petrobio (2.002 gram), Trichoderma (1.655 gram) dan kontrol (1.592 gram).

\section{SARAN}

Budidaya bawang merah dengan beberapa jenis jamur sebagai pupuk hayati perlu dikaji lagi lebih mendalam melalui kegiatan penelitian untuk mengetahui: pengaruhnya bila bawang merah ditanam pada musimnya; peningkatan dosis aplikasi; aplikasi kombinasi dengan pupuk kimia. Data yang diperoleh akan sangat berguna bagi para peserta pelatihan teknis budidaya bawang merah dan bagi para petani bawang merah sendiri.

\section{UCAPAN TERIMA KASIH}

Disampaikan kepada Kepala Balai Besar Pelatihan Pertanian Ketindan atas dukungan motivasi dan alokasi dana untuk menunjang kegiatan penelitian ini.

\section{DAFTAR PUSTAKA}

Akbari, G.A., S.M. Arab, H. A. Alikhani, I. Allahdadi and M.H. Arzanesh. 2007. Isolation and Selection of Indigenous Azospirillum spp. And the IAA of Superior Strains Effects on Wheat Roots. World Journal of Agricultural Sciences 3 (4): 523-529

Astiko, W. 2013. Peranan Mikoriza indigenus pada pola tanam berbeda dalam meningkatkan hasil kedelai di tanah berpasir (Studi Kasus di lahan Kering Lombok Utara). Disertasi. 
Uji Potensi Beberapa Jenis Pupuk Hayati pada Budidaya Bawang Merah (Juniawan)

Program Pascasarjana Universitas Brawijaya. Malang. 210 hal.

Okon, 1985. Azospirillum as a potential inoculant for agriculture. Trends in Biotechnology 3 (9) 223-228.

Okon and Kapulnik, 1986. Growth response of maize roots to Azospirillum inoculation: Effect of soil organic matter content, number of rhizosphere bacteria and timing of inoculation. Soil Biology and Biochemistry. Volume 20, issue 1. Pages 45-49
Rao, NSS. 1982. Mikroorganisme Tanah dan Pertumbuhan Tanaman. Edisi Kedua. UI-Press. Jakarta.158 hal.

Sastrahidayat, RS. 2011. Rekayasa Pupuk Hayati Mikoriza. UB Press. Malang. 237 hal.

Sukmadi, B.R., 2013. Aktivitas Fitohormon Indole-3-ACETIC ACID (IAA) dari Beberapa Isolat Bakteri Rizosfer dan Endofit. PUSPIPTEK BPPT. Serpong. 